\title{
The Air and Sewage Pollutants from Biological Waste Treatment
}

\author{
Marta Wiśniewska * (D) and Mirosław Szyłak-Szydłowski (D) \\ Faculty of Building Services, Hydro and Environmental Engineering, Warsaw University of Technology, \\ 20 Nowowiejska Street, 00-653 Warsaw, Poland; Miroslaw.Szydlowski@pw.edu.pl \\ * Correspondence: Marta.Wisniewska@pw.edu.pl
}

check for updates

Citation: Wiśniewska, M.; Szyłak-Szydłowski, M. The Air and Sewage Pollutants from Biological Waste Treatment. Processes 2021, 9 , 250. https://doi.org/10.3390/ pr9020250

Received: 4 December 2020

Accepted: 26 January 2021

Published: 29 January 2021

Publisher's Note: MDPI stays neutral with regard to jurisdictional claims in published maps and institutional affiliations.

Copyright: (C) 2021 by the authors. Licensee MDPI, Basel, Switzerland. This article is an open access article distributed under the terms and conditions of the Creative Commons Attribution (CC BY) license (https:// creativecommons.org/licenses/by/ $4.0 /)$.

\begin{abstract}
The mechanical-biological waste treatment plants (MBTP), which include the municipal waste biogas plants, have an important role in sustainable urban development. Some plants are equipped with a sewage pre-treatment plant, which is then directed to the sewerage system and the treatment plant. Others, on the other hand, have only a non-drainage tank. The parameters of technological sewage (TS) or processing technology could reduce sewage contamination rates. In addition to the quality of sewage from waste treatment plants, the emission of odours is also an important problem, as evidenced by the results obtained over the sewage pumping station tank. The conducted statistical analysis shows a significant positive correlation between odour concentration $\left(\mathrm{c}_{\mathrm{od}}\right)$ and volatile organic compounds (VOCs). Analysing the individual compounds, a high positive correlation was also found-the strongest being between $\mathrm{H}_{2} \mathrm{~S}, \mathrm{NH}_{3}$ and VOCs. In the case of sewage compounds, the insignificant correlation between $\mathrm{P}$ total and other parameters was found. For the rest of the compounds, the highest positive correlation was found between COD and BOD and $\mathrm{N}-\mathrm{NO}_{2}$ and $\mathrm{N}-\mathrm{NH}_{3}$ as well as $\mathrm{COD}$ and $\mathrm{N}-\mathrm{NO}_{2}$. The dilution of sewage is only an ad hoc solution to the problem. Further work should be aimed at reducing sewage pollution rates. The obtained results indicate large pollution of technological sewage and a high level of odour and odorants concentration. The novelty and scientific contribution presented in the paper are related to analyses of various factors on technological sewage parameters and odour and odorant emission from TS tank at biogas plant processing municipal waste, which may be an important source of knowledge on the management of TS, its disposal and minimisation of emitted compound emissions.
\end{abstract}

Keywords: biological treatment; chemical oxygen demand; odorant concentration; odour concentration; olfactometry; technological sewage

\section{Introduction}

The MBTP, which include the municipal waste biogas plants, an important element of sustainable management for future generations and a circular economy [1-4], are essential from the point of view of renewable energy, but also from minimising the odour nuisance of waste management facilities (the encapsulation of the first, most odorogenic phase of the biological process) [5]. The anaerobic digestion and composting are recommended for waste treatment processes, mainly for the biodegradable waste collected at the source. Both processes aim to convert waste into the least harmful form for the environment. The anaerobic digestion process is particularly proposed as an environmentally friendly and more cost-effective alternative to treating both household waste and waste activated sewage [6-12]. Nkoa [13] wrote that the digestate can cause, inter alia, nitrate leaching and ammonia emissions into the atmosphere. However, the inherent impact of waste treatment is the emission of the odorant compounds, but also of the production of technological sewage with a potentially high pollutant load [14,15]. The olfactory compounds characteristic of the waste management includes mainly VOCs (sulphur-containing VOCs, volatile fatty acids, phenolics and indolics), ammonia $\left(\mathrm{NH}_{3}\right)$ and hydrogen sulphide $\left(\mathrm{H}_{2} \mathrm{~S}\right)[16,17]$.

The TS is the leachate from individual waste treatment processes, e.g., treated at landfills, MBP plants and biogas plants, usually connected with rainwater. Technological 
(industrial) sewage is characterised by a high level of chemical oxygen demand (COD) as well as inorganic contaminants- $\mathrm{Ca}, \mathrm{Cu}, \mathrm{Mg}, \mathrm{Na}, \mathrm{Ni}, \mathrm{Zn}$ and $\mathrm{Ca}, \mathrm{Fe}$ and $\mathrm{Mg}$ which precipitate in the early phase of the process with the ammonium nitrogen [18]. Additionally, the storage process can emit greenhouse gases, i.e., methane and dinitrogen monoxide [19]. Unlike municipal wastewater, they usually contain certain types of pollutants, which makes their treatment process much more complex [20]. Nitrogen in wastewater is responsible for harmful gas emissions and nitric acid formation [21-25]. On the other hand, nitrogen is an important nutrient which allows the wastewater containing it to be used to improve the quality of soil or crops. The TS characterised by the high nitrogen concentration, discharged to sewerage systems, may contribute to the occurrence of the eutrophic conditions in the receiver $[22,25]$.

At the end of 2015, eight municipal waste treatment plants equipped with biogas installation have operated in Poland. Only at one of them is the biodegradable waste collected being selectively is used, while in the remaining ones in the fermentation process, the waste fraction is separated mechanically from the mixed waste stream (with granulation of approx. 20-80 $\mathrm{mm}$ ) [5]. In future, the amount of this type of biogas plants will probably increase, which is dictated by energy policy, as well as by changes in waste collection systems (the need for separate collection of biodegradable waste) [26,27]. Despite the many benefits of the plant, its operation is also associated with several technological problems, including the need to prepare the feedstock, the accumulation of volatile fatty acids, process instability, charge foaming, low buffer capacity, problematic wastewater production and high costs essential to waste transport and operation $[7,26,28]$.

The literature review has shown that there are few scientific studies on technological sewage from waste treatment processes and its odour emission. Wang et al. identified 49 odorants in the gas samples collected from the landfill leachate pipe. They were mainly hydrocarbons [29], sulphur compounds [15], halogenalkanes [2] and oxygenated hydrocarbons [3]. Among them, the key odorants were: mercaptans (odour contribution 45\%), m-xylene (odour contribution 13\%) and hydrogen sulphide (odour contribution 11\%) [29]. According to the Fang et al., he main odorous substances emitted from landfill site were styrene, toluene, xylene, acetone, methanol, n-butanone, n-butylaldehyde, acetic acid, dimethyl sulphide, dimethyl disulphide and ammonia. Therefore, in the leachate-related area, relatively low concentrations of all those odorants were detected in leachate storage pool [30]. However, in the below-mentioned researches, the odour concentration was not measured.

\section{Goal and Aim of the Study}

The analysis carried out in this work may contribute to the search for effective solutions to problems related to sewage from the anaerobic digestion process. This paper presents the analysis of sewage and odour emitted from the biological waste treatment process carried out at two waste treatment plants located in Poland. This work aims to analyse the impact of physico-chemical parameters of technological sewage on odour emission. The results of the analysis may be significant from the point of view of control of the technological processes conducted.

\section{Materials and Methods}

\subsection{Study Methodology}

The research includes fourteen series of measurements of sewage from waste storage and stabilization site at two municipal waste biogas plants located in Poland. The scope of the research includes both physical and chemical parameters of technological wastewater and gases emitted from the tank into which sew-age flows. The odorant concentration: ammonia (resolution: $1.0 \mathrm{ppm}$ ), volatile organic compounds (resolution $10 \mathrm{ppb}$ ), hydrogen sulphide (resolution: $0.1 \mathrm{ppm}$ ) and methyl mercaptan (resolution: $0.1 \mathrm{ppm}$ ) were determined using the MultiRae Pro portable gas detector with build-in a pumping system in five repetitions at each measurement site [26]. 
Olfactometer Nasal Ranger is a lightweight, portable device with two replaceable filter cartridges with activated carbon for air purification. It includes a built-in channel system for mixing and sharing gas streams-deliberate targeting is known part of the inhaled air by bypassing filters. The control valve is used to adjust one of the eleven values of $\mathrm{D} / \mathrm{T}$ $(2,4,7,15,30,60,100,200,300,400,500)$ and to set the value of "blank", at which the researcher breathes by purified air stream $[28,31]$.

Scentroid SM 100 is a field olfactometer, using compressed air from the cylinder under high pressure (31 $\mathrm{MPa}$ ) to dilute the test sample. The apparatus consists of a dilution valve control. Its high accuracy is used to provide a constant flow of diluted air through the device which allows the user to select one of the 15 positions, which correspond to ratios of clean air to the dilution of the test air sample. The range of the device is between 2 and $30,000 \mathrm{ou} / \mathrm{m}^{3}$, and the detection limit of the olfactometer is $3 \mathrm{ou} / \mathrm{m}^{3}[32,33]$.

The TS parameters were determined using the following methods: $\mathrm{pH}$ : PN-EN ISO 10523:2012 [34], ammonium nitrogen $\left(\mathrm{N}-N H_{3}\right)$ : PN-ISO 5664:2002 [35], total phosphorus

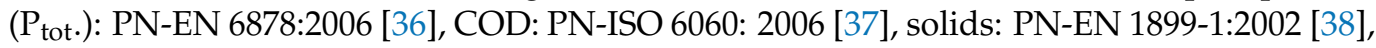
nitrate-nitrogen $\left(\mathrm{N}-\mathrm{NO}_{2}\right)$ : PN-EN 26777:1999 [39], BOD: PN-EN 1899-1:2002 [40].

The independent samples $t$-tests-Student, Welch and Mann-Whitney-were used to assess whether the means of two populations are equal to each other. To check assumptionsnormality and equality of variances-the Shapiro-Wilk's test and the Levene's test were made. To check correlations between examined variables, Pearson's r, Spearman's rho and Kendall Tau B coefficients were calculated. Furthermore, linear regression and Bayesian regression models were made. It contained four predictors with odour concentration as a dependent variable. Those regression analyses resulted in a hypothetical model of the relationship between the outcome and predictor variables. Bayesian linear regression model uses probability distributions rather than point estimates-its response is assumed from a probability distribution.

\subsection{Characteristic of Analysed Plants}

Both MWTP, which are the subject of the research, are mechanical-biological treatment installations of municipal waste which are equipped with biogas installation and methane fermentation in the biological part. The feedstock for the fermentation chambers at A plant is a fraction of biodegradable waste separated mechanically from the mixed waste stream and at plant B it is biodegradable waste selectively collected. The fermentation process is carried out under dry mesophilic conditions at both plants. The input material in the design assumption should be anaerobically treated for 21 days. At plant A, after this period, the digestate should be stabilised under aerobic conditions in an aeration chamber for 14 days and then subjected to a second-stage aerobic stabilisation at the ripening site for four weeks. Due to the limitations of the area of the technological yard on the premises of the plant, as well as a large amount of delivered waste, the plant periodically operates in "emergency mode". During these periods, the digestate is not always subjected to first and/or second-degree aerobic stabilisation after the end of the fermentation process but is sent to landfill. The measurements were carried out in the tank where flow sewage from stored, stabilized and composted waste and rainwater. This tank is a non-drainage tank, requiring periodic emptying and transport to the drainage station.

At plant B, after the first stage of the biological process (21 days), the digestate is directed to the processing site and there it undergoes oxygen stabilisation (approx. 28 days). The TS from the technological yard is directed by gravity to the collective sewage system (together with rainwater and domestic wastewater) and then is directed to a sewage treatment plant.

Sewage parameters were determined under laboratory conditions after earlier sampling directly from sewage tanks. The parameters of emitted gases were determined in field conditions using direct measurements. The measurements were taken from the sewage tanks. 


\section{Results and Discussion}

Table 1 contains the results of technological wastewater and air compounds determinations at both plants (A and $B)$.

Table 1. Results of technological wastewater and air compounds determinations in biogas plants A and B.

\begin{tabular}{|c|c|c|c|c|c|c|c|c|c|c|c|c|c|}
\hline \multirow{3}{*}{ Date } & \multirow{3}{*}{ Plant } & \multicolumn{7}{|c|}{ Technological Sewage } & \multicolumn{5}{|c|}{ Air } \\
\hline & & $\mathrm{pH}$ & COD & Solids & BOD & $\mathrm{N}-\mathrm{NO}_{2}$ & $\mathrm{~N}-\mathrm{NH}_{3}$ & $\mathbf{P}_{\text {tot. }}$ & $c_{\text {od }}$ & $\mathrm{NH}_{3}$ & VOC & $\mathrm{H}_{2} \mathrm{~S}$ & $\mathrm{CH}_{3} \mathrm{SH}$ \\
\hline & & - & \multicolumn{6}{|c|}{$\mathrm{mg} / \mathrm{dm}^{3}$} & ou $/ \mathrm{m}^{3}$ & \multicolumn{4}{|c|}{ ppm } \\
\hline 19.01.2018 & \multirow{14}{*}{ A } & 6.9 & 13,865 & 4204 & 7600 & 2.14 & 1352 & 49.1 & 678 & 55 & 20.34 & 35.1 & 10 \\
\hline 19.02.2018 & & 6.8 & 21,575 & 1393 & 15,000 & 2.67 & 1283 & 77.4 & 721 & 75 & 24.56 & 52.6 & 10 \\
\hline 14.05.2018 & & 6.7 & 31,876 & 1764 & 16,500 & 2.82 & 1184 & 42.4 & 3600 & 100 & 30.74 & 100 & 10 \\
\hline 21.06.2018 & & 7.3 & 2615 & 276 & 2151 & 0.642 & 210 & 5.45 & 31 & 4 & 2.50 & 0.1 & 0.1 \\
\hline 26.09 .2018 & & 7.2 & 2740 & 2142 & 976 & 0.799 & 311 & 12.3 & 22 & 6 & 1.95 & 0.1 & 0.1 \\
\hline 31.01.2019 & & 7.2 & 7642 & 3218 & 3227 & 1.64 & 901 & 32.5 & 78 & 15 & 5.46 & 10.1 & 8.4 \\
\hline 27.02.2019 & & 7.3 & 28,515 & 2168 & 15,750 & 2.8 & 1457 & 22.2 & 3600 & 100 & 20.1 & 100 & 100 \\
\hline 28.03.2019 & & 7.0 & 11,547 & 3515 & 6717 & 2.24 & 1051 & 30.7 & 656 & 42 & 4.57 & 32.4 & 10 \\
\hline 08.04.2019 & & 8.0 & 12,890 & 3896 & 4200 & 2.74 & 2816 & 57.1 & 678 & 54 & 6.14 & 42.3 & 10 \\
\hline 29.05.2019 & & 6.9 & 2114 & 228 & 915 & 0.523 & 205 & 22.2 & 22 & 4 & 1.56 & 1.4 & 3.2 \\
\hline 25.06 .2019 & & 6,8 & 2574 & 192 & 880 & 0.633 & 65.8 & 35.0 & 31 & 5 & 1.40 & 1.6 & 3.5 \\
\hline 25.07.2019 & & 7.6 & 5902 & 598 & 2550 & 1.51 & 953 & 39.4 & 187 & 14 & 2.64 & 0.1 & 0.3 \\
\hline 21.08.2019 & & 7.3 & 5788 & 396 & 2250 & 1.11 & 546 & 748 & 187 & 13 & 2.52 & 0.2 & 0.4 \\
\hline 26.09 .2019 & & 8.6 & 8115 & 760 & 2226 & 2.6 & 1706 & 43.4 & 246 & 25 & 2.42 & 0.6 & 0.6 \\
\hline 18.07.2019 & \multirow{8}{*}{ B } & 7.8 & 2050 & 250 & 790 & 0.1 & 138 & 12.0 & 2050 & 1 & 1 & 0 & 0 \\
\hline 01.08.2019 & & 7.8 & 2110 & 205 & 750 & 0.11 & 140 & 12 & 2110 & 1 & 1.3 & 0 & 0 \\
\hline 19.09.2019 & & 7.8 & 2150 & 203 & 720 & 0.12 & 138 & 13.0 & 2150 & 1 & 1 & 0 & 0 \\
\hline 10.10.2019 & & 7.8 & 2100 & 200 & 790 & 0.13 & 140 & 12 & 2100 & 1 & 0.9 & 0 & 0 \\
\hline 27.11.2019 & & 7.8 & 6390 & 511 & 3120 & 0.27 & 310 & 31.9 & 6390 & 1 & 0.3 & 0.5 & 3 \\
\hline 05.12.2019 & & 7.8 & 2180 & 203 & 800 & 0.13 & 142 & 13.0 & 2180 & 1 & 0.3 & 0.2 & 0.3 \\
\hline 11.12 .2019 & & 7.8 & 3050 & 643 & 1260 & 0.062 & 150 & 16.6 & 3050 & 1 & 0.3 & 1 & 1.5 \\
\hline 16.01 .2020 & & 7.8 & 2170 & 203 & 750 & 0.13 & 145 & 13.0 & 2170 & 0 & 0.19 & 0 & 0 \\
\hline
\end{tabular}

\subsection{Air Compounds}

Table 2 contains independent sample T-test results of air compounds determinations, while Table 3-its assumption checks.

The difference between the groups is statistically significant at the 0.05 level for $\mathrm{NH}_{3}$ and VOCs. Cohen's d was used as an effect size statistic for a paired $t$-test. It is calculated as the difference between the means of each group, all divided by the standard deviation of the data. The effect size was medium for $\mathrm{c}_{\mathrm{od}}$ and $\mathrm{CH}_{3} \mathrm{SH}$ and large for the rest of the effects. The assumption checks were statistically significant in most cases, except the normality test of VOCs in plant B and the test of variances equality for $\mathrm{CH}_{3} \mathrm{SH}$. For that last parameter, we consider the Welch version of the $t$-test, because the Welch version does not assume that the variances in the two groups are equal. Therefore, $p$ values calculated by both $t$-test versions were more than 0.05 .

Furthermore, the equivalence independent samples $t$-test was made, which allows one to test the null hypothesis that the population means of two independent groups fall inside a by the user-defined interval. This procedure follows the two-one-sided tests (TOST). Only when both the upper bound and the lower bound statistic are rejected, the initial non-equivalence hypothesis is rejected-in the present study, that situation was only in one case- $-\mathrm{CH}_{3} \mathrm{SH}$. In the rest cases, $p$-value for the lower bound test was $<0.05$, so the effect was smaller than or equal to the lower bound.

Figure 1 contains the correlation plot of air components, with Pearson's r, Spearman's rho and Kendall Tau B coefficients. 
Table 2. Results of independent sample T-test for air compounds determinations.

\begin{tabular}{ccccccc}
\hline & Test & Statistic & df & $p$ & VS-MPR * & Effect Size \\
\hline \multirow{2}{*}{ Cod } & Student & 1.489 & 20.000 & 0.152 & 1.284 & 0.660 \\
& Welch & 1.966 & 13.942 & 0.070 & 1.985 & 0.749 \\
& Mann-Whitney & 91.500 & & 0.017 & 5.409 & 0.634 \\
\hline \multirow{2}{*}{$\mathrm{NH}_{3}$} & Student & 2.855 & 20.000 & 0.010 & 8.127 & 1.265 \\
& Welch & 3.817 & 13.005 & 0.002 & 28.018 & 1.443 \\
& Mann-Whitney & 112.000 & & $<0.001$ & 346.388 & 1.000 \\
\hline \multirow{2}{*}{ VOC } & Student & 2.317 & 20.000 & 0.031 & 3.400 & 1.027 \\
& Welch & 3.095 & 13.083 & 0.008 & 9.096 & 1.170 \\
& Mann-Whitney & 112.000 & & $<0.001$ & 280.835 & 1.000 \\
$\mathrm{H}_{2} \mathrm{~S}$ & Student & 2.077 & 20.000 & 0.051 & 2.426 & 0.920 \\
& Welch & 2.776 & 13.005 & 0.016 & 5.634 & 1.049 \\
& Mann-Whitney & 99.500 & & 0.003 & 20.489 & 0.777 \\
$\mathrm{CH}_{3} \mathrm{SH}$ & Student & 1.228 & 20.000 & 0.234 & 1.083 & 0.544 \\
& Welch & 1.640 & 13.083 & 0.125 & 1.417 & 0.620 \\
\hline \multirow{2}{*}{$\mathrm{Note}$ For the } & Mann-Whitney & 99.500 & & 0.003 & 21.255 & 0.777 \\
\hline
\end{tabular}

Note. For the Student $t$-test and Welch $t$-test, the effect size is given by Cohen's d. For the Mann-Whitney test the effect size is given by the rank biserial correlation. * Vovk-Sellke Maximum $p$-Ratio: Based on a two-sided $p$-value, the maximum possible odds in favor of $\mathrm{H}_{1}$ over $\mathrm{H}_{0}$ equals $1 /(-\mathrm{e} p \log (p))$ for $p \leq 0.37$ (Sellke, Bayarri, and Berger, 2001).

Table 3. Assumptions checks for independent sample T-test results of air compounds determinations-the test of normality (Shapiro-Wilk test) and test of equality of variances (Levene test).

\begin{tabular}{|c|c|c|c|c|c|c|}
\hline & \multicolumn{3}{|c|}{ Normality } & \multicolumn{3}{|c|}{ Equality of Variances } \\
\hline & Plant & $\mathbf{W}$ & $p$ & F & df & $p$ \\
\hline \multirow{2}{*}{ Cod } & A & 0.609 & $<0.001$ & \multirow{2}{*}{4.41} & \multirow{2}{*}{1} & \multirow{2}{*}{0.049} \\
\hline & B & 0.689 & 0.002 & & & \\
\hline \multirow{2}{*}{$\mathrm{NH}_{3}$} & A & 0.841 & 0.017 & \multirow{2}{*}{23.5} & \multirow{2}{*}{1} & \multirow{2}{*}{$<0.001$} \\
\hline & $\mathrm{B}$ & 0.418 & $<0.001$ & & & \\
\hline \multirow{2}{*}{ VOC } & A & 0.740 & $<0.001$ & \multirow{2}{*}{20.5} & \multirow{2}{*}{1} & \multirow{2}{*}{$<0.001$} \\
\hline & B & 0.842 & 0.079 & & & \\
\hline \multirow{2}{*}{$\mathrm{H}_{2} \mathrm{~S}$} & $\mathrm{~A}$ & 0.757 & 0.002 & \multirow{2}{*}{15.6} & \multirow{2}{*}{1} & \multirow{2}{*}{$<0.001$} \\
\hline & B & 0.686 & 0.002 & & & \\
\hline \multirow{2}{*}{$\mathrm{CH}_{3} \mathrm{SH}$} & A & 0.441 & $<0.001$ & \multirow{2}{*}{2.20} & \multirow{2}{*}{1} & \multirow{2}{*}{0.153} \\
\hline & $\mathrm{B}$ & 0.648 & $<0.001$ & & & \\
\hline
\end{tabular}

The Pearson correlation coefficient is used to assess the linear relationship between the two variables. Kendall Tau B measures the monotonic relationship. While Kendall's Tau B is to be interpreted in terms of probability, Spearman's rho is to be interpreted in terms of the percentage of the variance of the rank of one variable explained by the other. For this reason, all three coefficients have been considered in these analyses. Almost all correlations are significant at alpha $=0.001$ level except the correlation between $\mathrm{CH}_{3} \mathrm{SH}$ and VOCs, which is significant at alpha $=0.05$ level. Therefore, all of them are significant. 


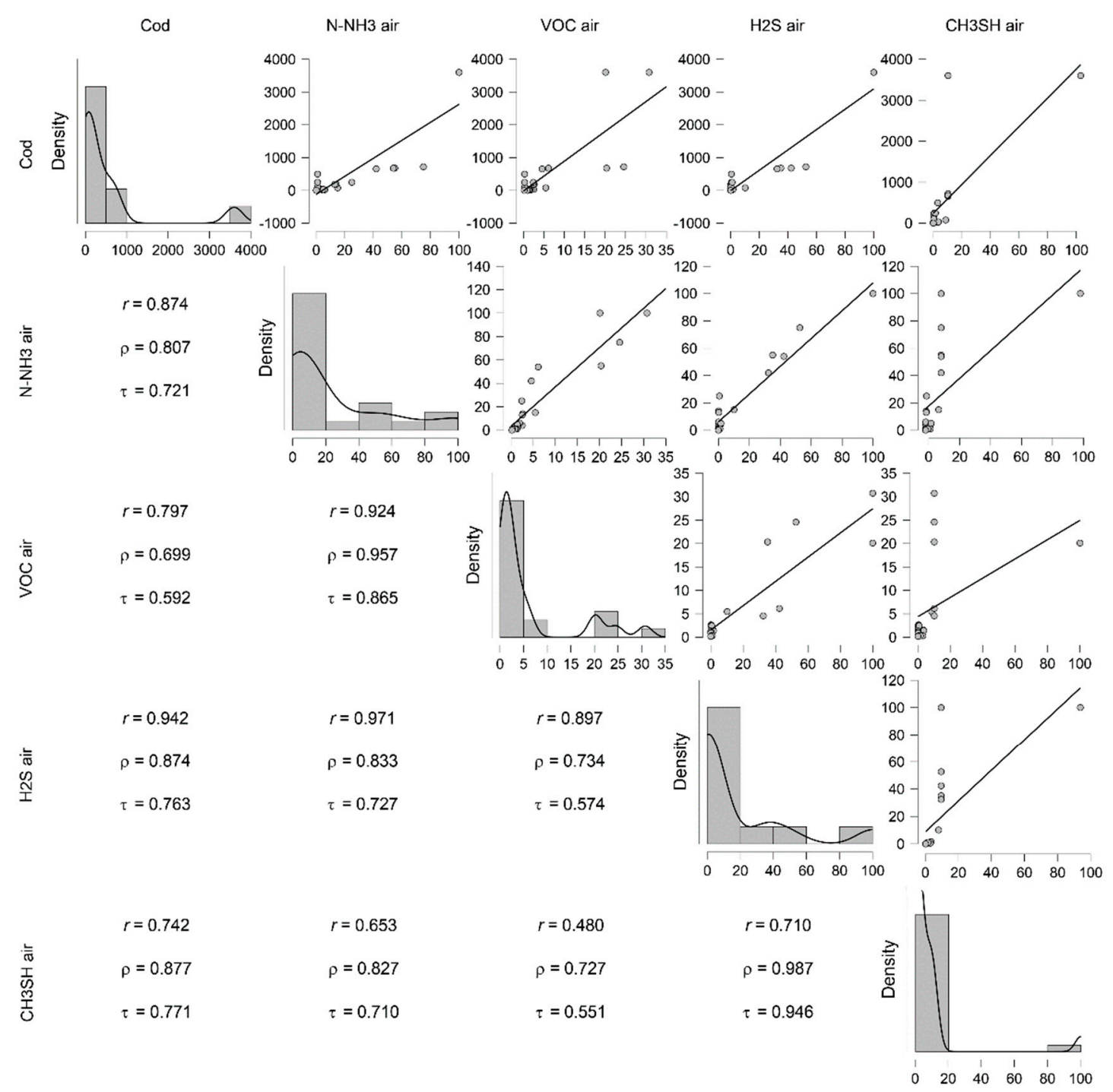

Figure 1. Correlation plot of air components, with Pearson's r, Spearman's rho and Kendall Tau B coefficients.

Considering values of Pearson's r, Spearman's rho and Kendall Tau B coefficients, correlation between odour concentrations and main odorants is high, between 0.7 and 0.9 (Pearson's r), 0.8 and 0.9 (Spearman's rho) as well as 0.7 and 0.8 (Kendall's Tau B). Correlation between odour concentration and VOCs is lower, but still high or moderate: 0.8 (Pearson's r), 0.7 (Spearman's rho) and 0.6 (Kendall's Tau B). Furthermore, considering Pearson's $\mathrm{r}$, there is a very high correlation between $\mathrm{H}_{2} \mathrm{~S}$ and $\mathrm{NH}_{3}$ and VOCs-coefficients are 0.9. Furthermore, correlation coefficient values are more than 0.9 in case of $\mathrm{NH}_{3}$ and VOCs. Considering Spearman's rho coefficient, correlations are moderate or high in all cases. The highest-more than 0.9 values of the correlation coefficient are for $\mathrm{CH}_{3} \mathrm{SH}$ and $\mathrm{H}_{2} \mathrm{~S}$ as well as $\mathrm{NH}_{3}$ and VOCs. In the case of Kendall's Tau B coefficient, its value is more than 0.9 for $\mathrm{H}_{2} \mathrm{~S}$ and $\mathrm{CH}_{3} \mathrm{SH}$. In rest cases, correlation is from moderate to high-the lowest (0.5) is for VOCs and $\mathrm{c}_{\mathrm{od}}, \mathrm{H}_{2} \mathrm{~S}$ and $\mathrm{CH}_{3} \mathrm{SH}$. All of $p$-values of the Shapiro-Wilk test for bivariate normality were $<0.001$.

The linear regression model-which contains four predictors with $\mathrm{c}_{\mathrm{od}}$ as the dependent variable — was made. The model coefficients are in Table 4. 
Table 4. Model coefficients with collinearity statistics.

\begin{tabular}{ccccccccc}
\hline Model & & Unstandardized & Standard Error & Standardized & $\mathbf{t}$ & $\boldsymbol{p}$ & Tolerance & VIF \\
\hline $\mathrm{H}_{0}$ & (Intercept) & 527.455 & 218.842 & & 2.410 & 0.025 & \\
$\mathrm{H}_{1}$ & (Intercept) & 122.349 & 95.979 & & 1.275 & 0.220 & \\
& $\mathrm{NH}_{3}$ & -20.877 & 10.359 & -0.664 & -2.015 & 0.060 & 0.042 & 23.645 \\
& $\mathrm{VOC}$ & 1.044 & 22.957 & 0.009 & 0.045 & 0.964 & 0.114 & 8.803 \\
& $\mathrm{H}_{2} \mathrm{~S}$ & 49.632 & 10.580 & 1.509 & 4.691 & $<0.001$ & 0.044 & 22.503 \\
& $\mathrm{CH}_{3} \mathrm{SH}$ & 4.864 & 5.459 & 0.100 & 0.891 & 0.385 & 0.368 & 2.717 \\
\hline
\end{tabular}

Note: Tolerance and VIF are collinearity statistics.

The $\mathrm{R}^{2}$ factor, 0.92 , is high and the adjusted $\mathrm{R}^{2}, 0.90$, drops only a little, showing robust model (probably not very high overfitting). The test of the fit of the model was also prepared. The explained variance of the model is statistically highly significant $(p<0.001)$. Therefore, the variance inflation factor is more than 10 for $\mathrm{NH}_{3}$ (24.6) and $\mathrm{H}_{2} \mathrm{~S}$ (22.5), so the multicollinearity in an ordinary least square is high. Furthermore, a Bayesian Linear Regression was made (Table 5).

Table 5. The Bayesian linear regression model.

\begin{tabular}{cccccc}
\hline Predictors Contained in the Model & $\mathbf{P ( M )}$ & $\mathbf{P}(\mathbf{M} \mid$ Data) & $\mathbf{B F}_{\mathbf{M}}$ & $\mathbf{B F}_{\mathbf{1 0}}$ & $\mathbf{R}^{\mathbf{2}}$ \\
\hline $\mathrm{NH}_{3}+\mathrm{H}_{2} \mathrm{~S}$ & 0.033 & 0.336 & 14.671 & 1.000 & 0.917 \\
$\mathrm{H}_{2} \mathrm{~S}$ & 0.050 & 0.318 & 8.875 & 0.632 & 0.888 \\
$\mathrm{NH}_{3}+\mathrm{H}_{2} \mathrm{~S}+\mathrm{CH}_{3} \mathrm{SH}$ & 0.050 & 0.094 & 1.977 & 0.187 & 0.922 \\
$\mathrm{NH}_{3}+\mathrm{VOC}+\mathrm{H}_{2} \mathrm{~S}$ & 0.050 & 0.065 & 1.310 & 0.128 & 0.918 \\
$\mathrm{VOC}+\mathrm{H}_{2} \mathrm{~S}$ & 0.033 & 0.063 & 1.956 & 0.188 & 0.900 \\
$\mathrm{H}_{2} \mathrm{~S}+\mathrm{CH}_{3} \mathrm{SH}$ & 0.033 & 0.054 & 1.670 & 0.162 & 0.899 \\
$\mathrm{NH}_{3}+\mathrm{VOC}+\mathrm{H}_{2} \mathrm{~S}+\mathrm{CH}_{3} \mathrm{SH}$ & 0.200 & 0.052 & 0.221 & 0.026 & 0.922 \\
$\mathrm{VOC}+\mathrm{H}_{2} \mathrm{~S}+\mathrm{CH}_{3} \mathrm{SH}$ & 0.050 & 0.016 & 0.307 & 0.032 & 0.903 \\
$\mathrm{NH}_{3}$ & 0.050 & $3.177 \times 10^{-4}$ & 0.006 & $6.305 \times 10^{-4}$ & 0.764 \\
$\mathrm{NH}_{3}+\mathrm{CH}_{3} \mathrm{SH}$ & 0.033 & $2.885 \times 10^{-4}$ & 0.008 & $8.587 \times 10^{-4}$ & 0.815 \\
\hline
\end{tabular}

Note: $\mathrm{P}(\mathrm{M})$ : Prior model probabilities. $\mathrm{P}\left(\mathrm{M} \mid\right.$ data): Posterior probabilities of the models considered. $\mathrm{BF}_{\mathrm{M}}$ : Posterior model odds. $\mathrm{BF}_{10}$ : Bayes factor. $\mathrm{R}^{2}$ : Explained variance.

The posterior model probabilities express the probability of a model after seeing the data. The Bayes factor quantifies the data-induced change from prior model odds to posterior model odds. The prior probability of the respective models was between 0.033 and 0.200 - the highest coefficient was in case of all four covariates. The maximum posterior model probabilities and the Bayes factor for the model were, respectively, 0.336 and 14.7-for $\mathrm{NH}_{3}+\mathrm{H}_{2} \mathrm{~S}$ variant. Maximum $\mathrm{R}^{2}$ coefficient was calculated for the sum of all four factors $\left(R^{2}=0.922\right)$.

\subsection{Technological Sewage Compounds}

Table 6 contains independent sample $T$-test results of air compounds determinations, while Table 7-its assumption checks.

The difference between the groups is statistically significant at the 0.05 level for all of compounds, except $\mathrm{P}$ total. The effect size statistic for a paired $t$-test was medium for $\mathrm{P}$ total and large for the rest of effects. The assumption checks were statistically significant in most cases, except test of normality of solids and $\mathrm{N}^{-\mathrm{NH}_{3}}$ at plant $\mathrm{A}$ and test of variances equality for $\mathrm{P}$ total at plant $\mathrm{B}$. Therefore, for that last parameter, we consider the Welch version of the $t$-test. According to the results of independent samples $t$-test for sewage results, reject initial non-equivalence hypothesis was rejected in two cases: $\mathrm{P}$ total and $\mathrm{c}_{\mathrm{od}}$. In the rest cases, the effect was smaller than or equal to the lower bound. 
Table 6. Results of independent sample T-test for technological sewage compounds determinations.

\begin{tabular}{|c|c|c|c|c|c|c|}
\hline & Test & Statistic & df & $p$ & VS-MPR * & Effect Size \\
\hline \multirow{3}{*}{ COD } & Student & 2.431 & 20.000 & 0.025 & 4.041 & 1.078 \\
\hline & Welch & 3.206 & 14.057 & 0.006 & 11.492 & 1.222 \\
\hline & Mann-Whitney & 99.000 & & 0.002 & 27.639 & 0.768 \\
\hline \multirow{3}{*}{ solids } & Student & 2.814 & 20.000 & 0.011 & 7.567 & 1.247 \\
\hline & Welch & 3.730 & 13.645 & 0.002 & 26.027 & 1.417 \\
\hline & Mann-Whitney & 96.000 & & 0.007 & 10.647 & 0.714 \\
\hline \multirow{3}{*}{ BOD } & Student & 2.250 & 20.000 & 0.036 & 3.080 & 0.997 \\
\hline & Welch & 2.971 & 13.917 & 0.010 & 7.886 & 1.131 \\
\hline & Mann-Whitney & 102.000 & & 0.002 & 31.060 & 0.821 \\
\hline \multirow{3}{*}{$\mathrm{N}-\mathrm{NO}_{2}$} & Student & 5.105 & 20.000 & $<0.001$ & 692.871 & 2.262 \\
\hline & Welch & 6.807 & 13.204 & $<0.001$ & 2805.832 & 2.577 \\
\hline & Mann-Whitney & 112.000 & & $<0.001$ & 279.760 & 1.000 \\
\hline \multirow{3}{*}{$\mathrm{N}-\mathrm{NH}_{3}$} & Student & 3.183 & 20.000 & 0.005 & 14.667 & 1.411 \\
\hline & Welch & 4.239 & 13.296 & $<0.001$ & 57.110 & 1.606 \\
\hline & Mann-Whitney & 102.000 & & 0.002 & 31.060 & 0.821 \\
\hline \multirow{3}{*}{$P_{\text {tot. }}$} & Student & 1.047 & 20.000 & 0.308 & 1.014 & 0.464 \\
\hline & Welch & 1.398 & 13.058 & 0.185 & 1.177 & 0.529 \\
\hline & Mann-Whitney & 96.000 & & 0.007 & 10.745 & 0.714 \\
\hline
\end{tabular}

Note. For the Student $t$-test and Welch $t$-test, effect size is given by Cohen's d. For the Mann-Whitney test, the effect size is given by the rank biserial correlation. * Vovk-Sellke Maximum p-Ratio: Based on a two-sided $\mathrm{p}$-value, the maximum possible odds in favour of $\mathrm{H}_{1}$ over $\mathrm{H}_{0}$ equals $1 /(-\mathrm{e} \mathrm{p} \log (\mathrm{p}))$ for $\mathrm{p} \leq 0.37$ (Sellke, Bayarr and Berger, 2001).

Table 7. Assumptions checks for independent sample T-test results of technological sewage compounds determinations-test of normality (Shapiro-Wilk test) and test of equality of variances (Levene test).

\begin{tabular}{|c|c|c|c|c|c|}
\hline & \multicolumn{3}{|c|}{ Normality } & \multicolumn{2}{|c|}{ Equality of Variances } \\
\hline & Plant & $\mathbf{W}$ & $p$ & $\mathbf{F}$ & $p$ \\
\hline \multirow{2}{*}{ COD } & A & 0.845 & 0.019 & \multirow{2}{*}{9.869} & \multirow{2}{*}{0.005} \\
\hline & $\mathrm{B}$ & 0.551 & $<0.001$ & & \\
\hline \multirow{2}{*}{ solids } & A & 0.888 & 0.075 & \multirow{2}{*}{13.399} & \multirow[b]{2}{*}{0.002} \\
\hline & $\mathrm{B}$ & 0.659 & $<0.001$ & & \\
\hline \multirow{2}{*}{ BOD } & A & 0.773 & 0.002 & \multirow{2}{*}{9.159} & \multirow[b]{2}{*}{0.007} \\
\hline & $\mathrm{B}$ & 0.551 & $<0.001$ & & \\
\hline \multirow{2}{*}{$\mathrm{N}-\mathrm{NO}_{2}$} & $\mathrm{~A}$ & 0.870 & 0.042 & \multirow{2}{*}{9.869} & \multirow{2}{*}{0.005} \\
\hline & $\mathrm{B}$ & 0.759 & 0.010 & & \\
\hline \multirow{2}{*}{$\mathrm{N}-\mathrm{NH}_{3}$} & A & 0.921 & 0.224 & \multirow{2}{*}{13.399} & \multirow{2}{*}{0.002} \\
\hline & $\mathrm{B}$ & 0.477 & $<0.001$ & & \\
\hline \multirow{2}{*}{$P_{\text {tot. }}$} & A & 0.384 & $<0.001$ & 9.159 & 0.007 \\
\hline & $\mathrm{B}$ & 0.574 & $<0.001$ & 2.356 & 0.140 \\
\hline
\end{tabular}

Figure 2 contains the correlation plot of technological sewage components, with Pearson's r, Spearman's rho and Kendall Tau B coefficients. P total was excluded from analysis since correlation coefficients were between -0.013 and 0.075 . All correlations of analysed components are significant at alpha $<0.05$ level (most of them $<0.001$ level). The highest correlation is between COD and BOD-Pearson's $\mathrm{r}$ correlation coefficient is 0.98 . There is also a very high correlation between $\mathrm{N}^{-\mathrm{NO}_{2}}$ and $\mathrm{N}-\mathrm{NH}_{3}$ (Pearson's rho 0.89) as well as COD and $\mathrm{N}-\mathrm{NO}_{2}(0.84)$. Therefore, Pearson's $\mathrm{r}$ correlation between solids and COD as well as $\mathrm{N}^{-\mathrm{NH}_{3}}$ and COD is, respectively, 0.51 and 0.54 , while Spearman's rho is, in the above cases, 0.82 and 0.89 . Generally, Spearman's rho correlation values are bigger than Pearson's $r$ and Kendall's tau — they are between 0.72 and 0.95 while Pearson's $r$ and 
Kendall's tau values are, $0.45-0.97$ and $0.50-0.84$, respectively. Almost all of $p$ values of Shapiro-Wilk test for bivariate normality were $<0.001$, except BOD-N-NO $2(p=0.002)$.

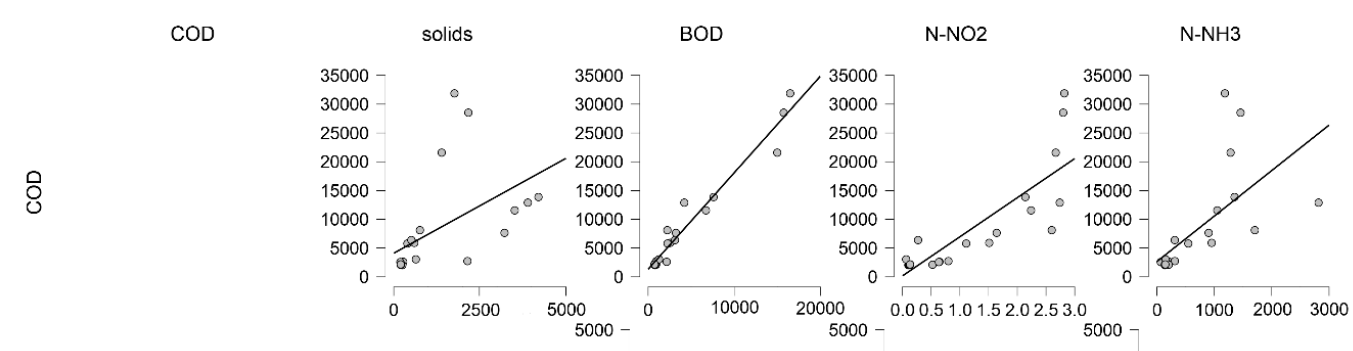

$\begin{array}{ll} & r=0.510 \\ \stackrel{\infty}{\circ} & \rho=0.822 \\ \frac{0}{6} & \tau=0.610\end{array}$

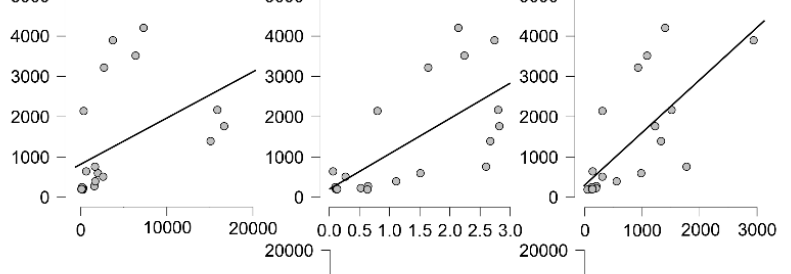

$\begin{array}{lll}r=0.977 & r=0.454 \\ \circ & \rho=0.947 & \rho=0.830 \\ \varnothing=0.839 & \tau=0.621\end{array}$

$\begin{array}{llll} & r=0.835 & r=0.697 & r=0.777 \\ \widetilde{O} & \rho=0.880 & \rho=0.724 & \rho=0.867 \\ \underset{z}{Z} & \tau=0.767 & \tau=0.500 & \tau=0.718\end{array}$

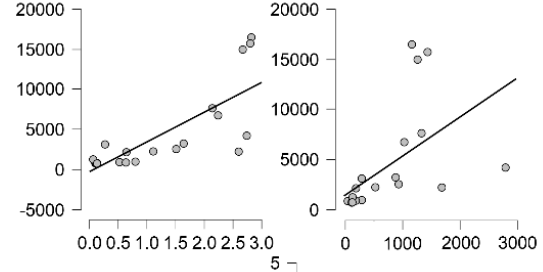

\begin{tabular}{|c|c|c|c|}
\hline$r=0.643$ & $r=0.721$ & $r=0.541$ & $r=0.894$ \\
\hline$\rho=0.890$ & $\rho=0.864$ & $\rho=0.863$ & $\rho=0.887$ \\
\hline$\tau=0.709$ & $\tau=0.683$ & $\tau=0.686$ & $\tau=0.735$ \\
\hline
\end{tabular}

Figure 2. Correlation plot of technological wastewater components, with Pearson's r, Spearman's rho and Kendall Tau B coefficients.

The linear regression model—which contains seven predictors with $\mathrm{c}_{\mathrm{od}}$ as the dependent variable—was made. Model coefficients there are in Table 8.

Table 8. Model coefficients with collinearity statistics.

\begin{tabular}{|c|c|c|c|c|c|c|c|c|}
\hline Model & & Unstandardized & Standard Error & Standardized & $\mathbf{t}$ & $p$ & Tolerance & VIF \\
\hline $\mathrm{H}_{0}$ & (Intercept) & 527.455 & 218.842 & & 2.410 & 0.025 & & \\
\hline \multirow[t]{8}{*}{$\mathrm{H}_{1}$} & (Intercept) & -866.332 & 1620.863 & & -0.534 & 0.601 & & \\
\hline & $\mathrm{pH}$ & 75.096 & 211.913 & 0.036 & 0.354 & 0.728 & 0.312 & 3.205 \\
\hline & COD & 0.311 & 0.042 & 2.654 & 7.428 & $<0.001$ & 0.025 & 40.031 \\
\hline & solids & -0.009 & 0.078 & -0.012 & -0.117 & 0.909 & 0.301 & 3.324 \\
\hline & BOD & -0.277 & 0.070 & -1.380 & -3.971 & 0.001 & 0.026 & 37.879 \\
\hline & $\mathrm{N}-\mathrm{NO}_{2}$ & -151.692 & 215.553 & -0.159 & -0.704 & 0.493 & 0.062 & 16.032 \\
\hline & $\mathrm{N}-\mathrm{NH}_{3}$ & -0.524 & 0.310 & -0.364 & -1.691 & 0.113 & 0.069 & 14.562 \\
\hline & $P_{\text {tot. }}$ & -0.348 & 0.403 & -0.052 & -0.863 & 0.403 & 0.865 & 1.156 \\
\hline
\end{tabular}

Note: Tolerance and VIF are collinearity statistics.

The $\mathrm{R}^{2}$ factor, 0.95 , is high and a little drop of the adjusted $\mathrm{R}^{2}, 0.93$, shows robust model (probably not very high overfitting). The explained variance of the model is statistically highly significant $(p<0.001)$. Therefore, the variance inflation factor is more than 10 for COD (40.0), BOD (37.9), $\mathrm{N}-\mathrm{NO}_{2}$ (16.0) and $\mathrm{N}-\mathrm{NH}_{3}$ (14.6), so the multicollinearity in 
an ordinary least square is high. Furthermore, a Bayesian Linear Regression was made (Table 9).

Table 9. The Bayesian linear regression model.

\begin{tabular}{|c|c|c|c|c|c|}
\hline Models & $P(M)$ & $\mathbf{P}(\mathbf{M} \mid$ data $)$ & $\mathrm{BF}_{\mathbf{M}}$ & $\mathbf{B F}_{10}$ & $\mathbf{R}^{2}$ \\
\hline $\mathrm{COD}+\mathrm{BOD}+\mathrm{N}-\mathrm{NH}_{3}$ & 0.004 & 0.337 & 141.804 & 1.000 & 0.947 \\
\hline $\mathrm{COD}+\mathrm{BOD}+\mathrm{N}-\mathrm{NO}_{2}$ & 0.004 & 0.123 & 39.034 & 0.364 & 0.940 \\
\hline $\mathrm{COD}+\mathrm{BOD}+\mathrm{N}-\mathrm{NO}_{2}+\mathrm{N}-\mathrm{NH}_{3}$ & 0.004 & 0.078 & 23.586 & 0.231 & 0.952 \\
\hline $\mathrm{COD}+\mathrm{BOD}+\mathrm{N}-\mathrm{NH}_{3}+\mathrm{P}_{\text {tot. }}$ & 0.004 & 0.073 & 21.917 & 0.216 & 0.951 \\
\hline $\mathrm{pH}+\mathrm{COD}+\mathrm{BOD}+\mathrm{N}-\mathrm{NH}_{3}$ & 0.004 & 0.067 & 20.157 & 0.200 & 0.951 \\
\hline $\mathrm{COD}+$ solids $+\mathrm{BOD}+\mathrm{N}-\mathrm{NH}_{3}$ & 0.004 & 0.041 & 11.833 & 0.121 & 0.948 \\
\hline $\mathrm{COD}+\mathrm{BOD}+\mathrm{N}-\mathrm{NO}_{2}+\mathrm{N}-\mathrm{NH}_{3}+\mathrm{P}_{\text {tot. }}$ & 0.006 & 0.025 & 4.317 & 0.045 & 0.954 \\
\hline $\mathrm{pH}+\mathrm{COD}+\mathrm{BOD}+\mathrm{N}-\mathrm{NH}_{3}+\mathrm{P}_{\text {tot. }}$ & 0.006 & 0.023 & 3.847 & 0.040 & 0.954 \\
\hline $\mathrm{pH}+\mathrm{COD}+\mathrm{BOD}+\mathrm{N}-\mathrm{NO}_{2}+\mathrm{N}-\mathrm{NH}_{3}$ & 0.006 & 0.020 & 3.357 & 0.035 & 0.953 \\
\hline $\mathrm{COD}+$ solids $+\mathrm{BOD}+\mathrm{N}-\mathrm{NO}_{2}$ & 0.004 & 0.018 & 5.173 & 0.054 & 0.942 \\
\hline
\end{tabular}

Note: $\mathrm{P}(\mathrm{M})$ : Prior model probabilities. $\mathrm{P}\left(\mathrm{M} /\right.$ data): Posterior probabilities of the models considered. $\mathrm{BF}_{\mathrm{M}}$ : Posterior model odds. $\mathrm{BF}_{10}$ : Bayes factor. $\mathrm{R}^{2}$ : Explained variance.

The prior probability of the respective models was between 0.004 and 0.006 . The maximum posterior the model probabilities and the Bayes factor for model were 0.337 and 141.8 respectively-for $\mathrm{COD}+\mathrm{BOD}+\mathrm{N}-\mathrm{NH}_{3}$ variant. Maximum $\mathrm{R}^{2}$ coefficient was calculated for the sum of all four factors $\left(\mathrm{R}^{2}=0.954\right)$ and the sum of them, without $\mathrm{N}-\mathrm{NO}_{2}$.

\subsection{Air and Technological Wastewater Compounds}

Figure 3 contains the heatmap of Spearman's rho correlation coefficient of air and TS compounds.

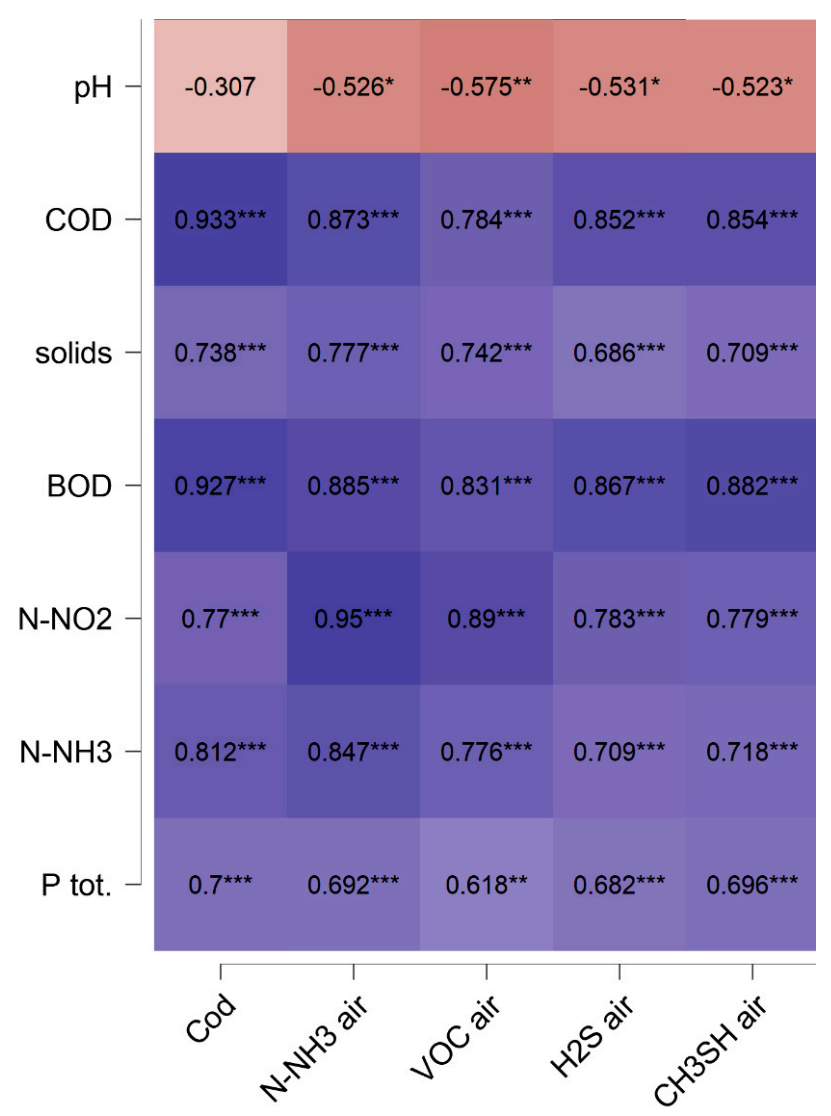

Figure 3. Heatmap of Spearman's rho correlation coefficient of air and technological wastewater compounds. Note: ${ }^{*} p<0.05,{ }^{* *} p<0.01,{ }^{* * *} p<0.001$. 
For the $\mathrm{pH}$ of process wastewater, the correlation coefficients were negative. Statistically significant were six out of eleven-the correlation coefficient of $\mathrm{pH}$ and other parameters ranged from -0.4 to -0.5 .

In the remaining cases, correlation analyses of technological wastewater compounds, odour and air pollution concentrations, Spearman's rho correlation coefficients ranged from 0.6 (VOCs- $\left.P_{\text {tot. }}\right)$ to 0.9 ( $\left.\mathrm{cod}_{\mathrm{od}}-\mathrm{COD}\right)$. Very high $(>0.8)$ correlation coefficients were also determined for BOD and all the air compounds, as well as COD and almost all air compounds, apart from VOCs, also for pairs: $\mathrm{N}-\mathrm{NO}_{2}-\mathrm{NH}_{3}$ air, $\mathrm{NO}_{2}-\mathrm{VOCs}, \mathrm{N}-\mathrm{NH}_{3}-\mathrm{C}_{\mathrm{od}}$, and $\mathrm{NH}_{3}$ air.

\section{Conclusions}

The carried out research allowed to draw the following conclusions:

1. None of the air pollution concentration values-ammonia, hydrogen sulphide and methyl mercaptan-meet the permissible reference values for assessing the degree of air pollution-respectively, $0.533 \mathrm{ppm}, 0.013 \mathrm{ppm}$ and $0.009 \mathrm{ppm}$ (Regulation of the Minister of the Environment of 26 January 2010 on reference values for some substances in the air) [41].

2. At AMWTP, where sewage is stored in a tank and only periodically pumped out, much higher values of both sewage and air parameters were observed than in the case of biogas plant A equipped with a sewage system, thanks to which sewage is directed to a sewage treatment plant.

3. The analysis of the results of air compounds shown a significant positive correlation between the odour concentration and both the main odorogenic and volatile organic compounds. Analysing the individual compounds, a high positive correlation was also found - the strongest between $\mathrm{H}_{2} \mathrm{~S}, \mathrm{NH}_{3}$ and VOCs.

4. After analysis of the results of sewage compounds, the insignificant correlation between $\mathrm{P}$ total and other parameters was found. For the rest of the compounds, the highest positive correlation was found between $\mathrm{COD}$ and $\mathrm{BOD}$ and $\mathrm{N}-\mathrm{NO}_{2}$ and $\mathrm{N}-\mathrm{NH}_{3}$ as well as COD and $\mathrm{N}-\mathrm{NO}_{2}$.

5. According to the results, the impact of physico-chemical parameters of technological sewage on odour emission was significant-the strong correlation was observed between odour concentration and chosen air and wastewater parameters. To make these relationships more accurate, linear regression models were performed, which were characterized by high determination coefficients.

6. Municipal waste treatment plants, especially those equipped with a biogas installation, are an indispensable element of urban infrastructure as well as an important part of a circular economy. Therefore, it is important to support the technological processes carried out at plants by analysing them in scientific studies. TS from biological waste treatment processes is very persistent, due to its diverse and variable composition, as well as uncontrolled emission of odours from tanks intended for their storage. The presented research results show the essence and complexity of the raised issues.

7. It seems advisable to extend the research conducted in this study with an analysis related to the biomethane potential of technological wastewater after the fermentation process. Such a study for household food waste was conducted by Lytras et al. [12]. The mentioned researchers analysed the co-digestion of waste activated sludge and condensate, produced through drying and shredding of source-separated collected food waste, which proved to be an effective method for its valorisation.

Author Contributions: M.W.: data collection, conceptualization, methodology, investigation, writingoriginal draft preparation, supervision; M.S.-S.: writing-review and editing, visualisation, validation. All authors have read and agreed to the published version of the manuscript.

Funding: Work was co-financed by Warsaw University of Technology, Scientific Discipline of Environmental Engineering, Mining and Energy 
Institutional Review Board Statement: Not applicable.

Informed Consent Statement: Not applicable.

Data Availability Statement: Data available on request due to for not publishing them until now.

Conflicts of Interest: The authors declare no conflict of interest.

\section{References}

1. Fan, Y.V.; Klemeš, J.J.; Walmsley, T.G.; Bertók, B. Implementing Circular Economy in municipal solid waste treatment system using P-graph. Sci. Total Environ. 2020, 701, 134652. [CrossRef]

2. Karak, T.; Bhagat, R.M.; Bhattacharyya, P. Municipal Solid Waste Generation, Composition, and Management: The World Scenario. Crit. Rev. Environ. Sci. Technol. 2012, 42, 1509-1630. [CrossRef]

3. Migliori, M.; Catizzone, E.; Giordano, G.; Le Pera, A.; Sellaro, M.; Lista, A.; Zanardi, G.; Zoia, L. Pilot Plant Data Assessment in Anaerobic Digestion of Organic Fraction of Municipal Waste Solids. Sensors 2019, 7, 54. [CrossRef]

4. Pires, A.; Martinho, G.; Chang, N.B. Solid waste management in European countries: A review of systems analysis techniques. J. Environ. Manag. 2011, 92, 1033-1050. [CrossRef] [PubMed]

5. Wiśniewska, M.; Kulig, A.; Lelicińska-Serafin, K. Comparative analysis of preliminary identification and characteristic of odour sources in biogas plants processing municipal waste in Poland. SN Appl. Sci. 2019, 1, 550. [CrossRef]

6. $\quad$ Oh, J.-I.; Lee, J.; Lin, K.-Y.A.; Kwon, E.E.; Tsang, Y.F. Biogas production from food waste via anaerobic digestion with wood chips. Energy Environ. 2018, 29, 1365-1372. [CrossRef]

7. Xu, F.; Li, Y.; Ge, X.; Yang, L.; Li, Y. Anaerobic digestion of food waste-Challenges and opportunities. Bioresour. Technol. 2018, 247, 1047-1058. [CrossRef] [PubMed]

8. Pramanik, S.K.; Suja, F.B.; Zain, S.M.; Pramanik, B.K. The anaerobic digestion process of biogas production from food waste: Prospects and constraints. Bioresour. Technol. Rep. 2019, 8, 100310. [CrossRef]

9. Kader, F.; Baky, A.H.; Khan, M.N.H.; Chowdhury, H.A. Production of Biogas by Anaerobic Digestion of Food Waste and Process Simulation. Am. J. Mech. Eng. 2015, 3, 79-83. [CrossRef]

10. Fisgativa, H.; Tremier, A. Influence of food waste characteristics variations on treatability through anaerobic digestion. In Proceedings of the 16th International Conference Rural-Urban Symbiosis (RAMIRAN), Hamburg, Germany, 8-10 September 2015.

11. Xu, Y.; Lu, Y.; Zheng, L.; Wang, Z.; Dai, X. Perspective on enhancing the anaerobic digestion of waste activated sludge. J. Hazard. Mater. 2020, 389, 121847. [CrossRef]

12. Lytras, G.; Koutroumanou, E.; Lyberatos, G. Anaerobic co-digestion of condensate produced from drying of Household Food Waste and Waste Activated Sludge. J. Environ. Chem. Eng. 2020, 8, 103947. [CrossRef]

13. Nkoa, R. Agricultural benefits and environmental risks of soil fertilization with anaerobic digestates: A review. Agron. Sustain. Dev. 2014, 34, 473-492. [CrossRef]

14. Font, X.; Artola, A.; Sánchez, A. Detection, Composition and Treatment of Volatile Organic Compounds from Waste Treatment Plants. Sensors 2011, 11, 4043-4059. [CrossRef]

15. Nguyen, M.T.; Maeda, T.; Yusoff, M.Z.M.; Ogawa, H.I. Effect of azithromycin on enhancement of methane production from waste activated wastewater. J. Ind. Microbiol. Biotechnol. 2014, 41, 1051-1059. [CrossRef] [PubMed]

16. Capelli, L.; Sironi, S.; Del Rosso, R.; Guillot, J.M. Measuring odours in the environment vs. dispersion modelling: A review. Atmos. Environ. 2013, 79, 731-743. [CrossRef]

17. Maurer, D.L.; Koziel, J.A.; Kalus, K.; Andersen, D.S.; Opalinski, S. Pilot-Scale Testing of Non-Activated Biochar for Swine Manure Treatment and Mitigation of Ammonia, Hydrogen Sulfide, Odorous Volatile Organic Compounds (VOCs), and Greenhouse Gas Emissions. Sustainability 2017, 9, 929. [CrossRef]

18. Molleda, A.; Lopez, A.; Cuartas, M.; Lobo, A. Release of pollutants in MBT landfills: Laboratory versus field. Chemosphere 2020, 249, 126-145. [CrossRef]

19. Monlau, F.; Sambusiti, C.; Ficara, E.; Aboulkas, A.; Barakat, A.; Carrere, H. New opportunities for agricultural digestate valorization: Current situation and perspectives. Energy Environ. Sci. 2015, 8, 2600-2621. [CrossRef]

20. Minière, M.; Boutin, O.; Soric, A. Combination of chemical and biological processes to enhance the treatment of hardly biodegradable matter in industrial wastewater: Selection parameters and performances. Can. J. Environ. Eng. 2019, 97. [CrossRef]

21. Filbakk, T.; Jirjis, R.; Nurmi, J.; Høibø, O. The effect of bark content on quality parameters of Scots pine (Pinus sylvestris L.) pellets. Biomass Bioenergy 2011, 35, 3342-3349. [CrossRef]

22. Garbowski, T. Changes in the Physico-Chemical Parameters of Water as a Result of Long-Term Contact with Biomass, on the Example of Pine Bark (Pinus sylvestris). Water Air Soil Pollut. 2019, 230, 104. [CrossRef]

23. Mace, K.A.; Artaxo, P.; Duce, R.A. Water-soluble organic nitrogen in Amazon Basin aerosols during the dry (biomass burning) and wet seasons. J. Geophys. Res. 2003, 108, 1-10. [CrossRef]

24. Vamvuka, D.; Sfakiotakis, S. Effects of heating rate and water leaching of perennial energy crops on pyrolysis characteristics and kinetics. Renew. Energy 2011, 36, 2433-2439. [CrossRef]

25. Vassilev, S.V.; Vassileva, C.G.; Vassilev, V.S. Advantages and disadvantages of composition and properties of biomass in comparison with coal: An overview. Fuel 2015, 158, 330-350. [CrossRef] 
26. Wiśniewska, M.; Kulig, A.; Lelicińska-Serafin, K. The Impact of Technological Processes on Odorant Emissions at Municipal Waste Biogas Plants. Sustainability 2020, 12, 5457. [CrossRef]

27. Wiśniewska, M.; Kulig, A.; Lelicińska-Serafin, K. Olfactometric testing as a method for assessing odour nuisance of biogas plants pro-cessing municipal waste. Arch. Environ. Prot. 2020, 46, 60-68. [CrossRef]

28. Szyłak-Szydłowski, M. Comparison of two types of field olfactometers for assessing odours in laboratory and field tests. Chem. Eng. Trans. 2014, 40, 67-72. [CrossRef]

29. Wang, X.; Parcsi, G.; Sivret, E.; Le, M.; Stuetz, R. Odorants and their contributions to overall odour emission from a landfill leachate. Atmosphere 2019, 10. [CrossRef]

30. Fang, J.-J.; Jang, N.; Cen, D.-Y.; Shao, L.-M. Odor compounds from different sources of landfill: Characterization and source identification. Waste Manag. 2012, 32, 1401-1410. [CrossRef]

31. Kulig, A.; Szyłak-Szydłowski, M. Assessment of the effects of wastewater treatment plant modernization by means of the field olfactometry method. Water 2019, 11, 2367. [CrossRef]

32. Szyłak-Szydłowski, M. Odour Samples Degradation During Detention in Tedlar Bags. Water Air Soil Pollut. 2015, $226,227$. [CrossRef] [PubMed]

33. Szyłak-Szydłowski, M. Validation of odour concentration from MBT piles using static chamber and wind tunnel with the different wind speed values. J. Air Waste Manag. Assoc. 2017, 67. [CrossRef] [PubMed]

34. The Polish Committee for Standardization. PN-EN ISO 10523:2012. Water Quality. Determination of $p H$; The Polish Committee for Standardization: Warsaw, Poland, 2012.

35. The Polish Committee for Standardization. PN-EN 5664:2002. Water Quality. Determination of Ammonium Nitrogen. Distillation Method with Titration; The Polish Committee for Standardization: Warsaw, Poland, 2002.

36. The Polish Committee for Standardization. PN-EN ISO 6878:2006. Water Quality. Determination of Phosphorus. Ammonium Molybdate Spectrometric Method; The Polish Committee for Standardization: Warsaw, Poland, 2006.

37. The Polish Committee for Standardization. PN-EN 6060:2006. Water Quality. Determination of Chemical Oxygen Demand. Titration Method. Chemical Index; The Polish Committee for Standardization: Warsaw, Poland, 2006.

38. The Polish Committee for Standardization. PN-EN 872:2007+Ap 1:2007. Water and Wastewater. Determination of Solids. Method Using Filtration through Glass Fibre Filters; The Polish Committee for Standardization: Warsaw, Poland, 2007.

39. The Polish Committee for Standardization. PN-EN 26777:1999. Water Quality. Determination of Nitrite. Molecular Absorption Spectrometric Method; The Polish Committee for Standardization: Warsaw, Poland, 1999.

40. The Polish Committee for Standardization. PN-EN 1899-1:2002. Water Quality. Determination of Biochemical Oxygen Demand after $n$ Days (BOD)_Part 1: Dilution Method and Vaccination with Allylthiourea; The Polish Committee for Standardization: Warsaw, Poland, 2002.

41. FAO. Regulation establishing reference values for certain substances in the air. J. Laws 2010, 16, 87. 